\title{
My Anger Is Your Gain, My Contempt Your Loss: Explaining Consumer Responses to Corporate Wrongdoing
}

\author{
Simona Romani \\ LUISS Guido Carli \\ Silvia Grappi \\ University of Modena and Reggio Emilia
}

Richard P. Bagozzi

University of Michigan

\begin{abstract}
Two forms of consumer response to corporate wrongdoing are constructive punitive actions (i.e., those designed to induce firms to change their behavior but with the hope of sustaining relationships with consumers) and destructive punitive actions (i.e., those intended to discredit or harm firms, ultimately leading to disengagement from firms). This study investigates the conditions under which one or the other actions are taken and shows that anger regulates the former, whereas contempt governs the latter. Hypotheses are tested in two studies: a laboratory experiment and a naturalistic field study with an actual instance of recent corporate malfeasance. Theoretical and managerial implications are discussed. (c) 2013 Wiley Periodicals, Inc.
\end{abstract}

Consumers are particularly sensitive to poor corporate social responsibility (CSR) performance, and their negative reactions can take many forms, ranging from bland reactions, to moderately forceful actions, to more radical ones. Considerable empirical research has examined consumer reactions to perceived wrongdoings by companies in a wide range of contexts (e.g., Klein, Smith, \& John, 2004; Micheletti, 2003; Sen, GurhanCanli, \& Morwitz, 2001). Although this research provides important insights into the processes underpinning consumer reactions to corporate wrongdoing, little is known about the conditions leading to differential consumer responses and the role that moral emotions play in initiating and guiding these responses. Indeed, as developed below, discrete moral reactions in the form of subtle distinctions between anger and contempt lead to unique, separable consumer actions. Such an approach follows a recent call by Bhattacharya, Korschun, and Sen (2009) to ground research in CSR in sound psychological and social theoretical mechanisms. Such work also speaks to recent efforts in business research to understand such diverse phenomena as consumer complaint behavior and market activism (Kozinets \& Handelman, 2004; Palazzo \& Basu, 2007; Thompson \& Arsel, 2004), and could yield vital information for managers and policy makers concerned with understanding when and how consumers and other stakeholders influence firms to change their behaviors (Laczniak \& Murphy, 2012; Smith, Palazzo, \& Bhattacharya, 2010).

To address this gap in the literature, this article investigates emotional instigators of two different consumer reactions to offensive corporate performance. Specifically, a distinction is made between constructive punitive actions-actions directed to achieving a modification of companies' conduct by maintaining relationships with them-and destructive punitive actionsactions directed at creating a negative image of the company and avoidance of its brands; and it is proposed that the former are driven primarily by anger toward firms, whereas contempt, which encompasses an urge to create psychological distance from firms and avoidance of reconciliatory intentions, influences the latter. Before the outlining of hypotheses and their rationale, research on consumer reactions to corporate wrongdoings is summarized.

\section{CORPORATE WRONGDOING AND CONSUMER REACTIONS}

Corporate wrongdoing occurring in ethical, environmental, and social contexts can be interpreted as 
violations of moral standards based on (a) traditional theories of morality (Turiel, 1983), which emphasize concerns about individuals directly harming and unfairly treating others, and (b) recent theoretical approaches on morality, which take a broad view on ethical behavior (e.g., Haidt, 2007; Haidt, Koller, \& Dias, 1993; Shweder, Much, Mahapatra, \& Park, 1997). It suggests that moral concerns go beyond individualbased issues of personal harm and fairness (termed in the literature, violation of the ethics of autonomy in the sense of disregard of human dignity or freedom), to also encompass (1) moral disgust and (2) concerns about respect, duty, and hierarchical relations.

Corporate actions that violate the rights of individuals, the environment, social relationships, or institutions may in fact have intrinsically harmful consequences for others, such as in the case of human rights violations and environmental degradation, or may have interpersonal or group consequences that are not intrinsically harmful, yet are meaningful in the context of a specific social system, such as found in instances of disrespect of the natural order of a community. These violations of moral systems induce consumers to feel "calls to action" against corporate wrongdoers to one degree or another. Two major areas of research offer theoretical insights, explaining how and when consumers react in the face of corporate misconduct. These are found in the literatures on political consumerism and antibrand activism.

Micheletti (2003, p. 2) suggests that political consumerism "represents actions by people who make choices among producers and products with the goal of changing objectionable institutional or market practices. Their choices are based on attitudes and values regarding issues of justice, fairness, or non-economic issues that concern personal and family well-being and ethical or political assessment of favorable and unfavorable business and government practice." Political consumerism may involve both individual and collective actions and takes a negative (e.g., boycott) or positive (e.g., buycott) form (e.g., Neilson, 2010). Until now empirical research has focused attention almost exclusively on consumer boycotts directed to changing a corporation's controversial behavior. A common starting point of this research is that consumers negatively respond to a firm's behavior considered wrong and that has negative and possibly harmful consequences for various entities or stakeholders (Hoffmann \& Muller 2009; Klein, Smith, \& John, 2004; Kozinets \& Handelman, 1998; Sen, Gurhan-Canli, \& Morwitz, 2001).

Research into antibrand activism shows that such activism forms around individuals' disapproval of corporate actions and desire to achieve social justice (Hollenbeck \& Zinkhan, 2010). Examples of recent studies on the topic include the following: antiStarbucks (Thompson \& Arsel, 2004), anti-Wal-Mart, anti-McDonald (Hollenbeck \& Zinkhan, 2006), and anti-Nike and anti-GE activism (Kozinets \& Handel- man, 2004). A common element emerging from this, mainly qualitative, research is that people naturally respond to a sense of disadvantage, unjust treatment, or threat to themselves or perceived in others (consumers, community, and environment). Consumers engage in antibrand activities as a result of viewing the presence of injustices in the marketplace with attributions of corporations as being "oppressive," "exploitive," "destructive," "unethical," and "monopolizing" (Hollenbeck \& Zinkhan, 2006). Issues of injustice, dishonesty, and unfair advantages are central motivations for activists, where brand avoidance results as main outcome.

Although these two research streams discuss different forms of consumer reactions, they share a common solicitude for the welfare of people and environment and a common goal to act so as to rectify wrongdoing. Yet both have largely ignored key negative emotional reactions elicited by appraisals of company misconduct and the important role of such feelings in arousing consumer action. Negative moral emotions, in particular, should play central roles here, given the broader moral issues involved. Such emotions have been formed to be strong reactions and effective determinants of action in basic research by psychologists into general moral behavior.

Based on recent research by neuroscientists and psychologists (e.g., Haidt, 2001, 2007), moral emotions represent basic elements, linking moral standards to moral judgments and/or moral behaviors. Tangney, Stuewig, and Mashek (2007) also stress that moral emotions represent an important element of an individual's moral apparatus and may be critically important in explaining people's behavior in moral domains.

Research in psychology implies that consumer appraisals of wrongdoing done by companies should arouse moral feelings together with their associated action tendencies. In the psychology literature, contempt, anger, and disgust are related, but distinguishable, moral emotional reactions to moral violations of others, which have been mainly investigated by psychologists to date (e.g., Haidt, 2003; Izard, 1977; Rozin, Lowery, Imada, \& Haidt, 1999) and are particularly relevant in our specific context. These moral emotions can occur individually or jointly to express different types of disapproval for the actions of other people, when these actions violate moral standards. These emotions, therefore, function as guardians of different portions of the moral order so to speak (Haidt, 2003) and motivate people to act to repair the moral order and to make violators change their behaviors when moral transgressions occur.

Focus herein is on the motivational and behavioral components of the moral emotions in response to corporate transgressions and their ultimate effects on consumer behavior. In particular, by scrutinizing anger and contempt, and building on the work done on the functional differences between them, and controlling for disgust and values (e.g., Fischer \& Roseman, 2007; Hutcherson \& Gross, 2011), very different effects are 
proposed and found for these two moral emotions on consumer reactions to corporate wrongdoings. ${ }^{1}$

\section{HYPOTHESES}

The mediating role of negative moral emotions is examined between perceptions of corporate misconduct and decisions to take actions against corporations. In the literature on marketing and consumer behavior, specific analysis and classification of different forms of consumer reactions do not exist. Inspired by the research reviewed above, a distinction is made herein between constructive punitive actions (i.e., actions directed at changing or redirecting corporate practices by maintaining or enhancing relationships with companies, such as demonstrations, e-mail campaigns, or temporary boycotts) and destructive punitive actions (i.e., actions directed at harming the corporation and promoting the avoidance of its products, such as discrediting the company and its wares, and talking badly about them ${ }^{2}$ ).

For constructive punitive actions, the focus of consumers is on changing wrong policies and practices of companies with the hope of continuing the relationship with them in a positive way. The goal is to redirect corporate conduct in more sustainable and equitable directions from existing relationships, or, in some instances, temporarily refraining from purchasing a company's products so as to re-engage with the firm once certain conditions are met, such as change in corporate policies. In such cases, the relationship between consumers and company ultimately improves. An interesting example of the connections between constructive punitive actions (specifically a temporary boycott campaign), redirection in company policies, and consumer satisfaction is Benetton (Friedman, 1996). Benetton made changes in policies concerning abuse of lambs and sheep by suppliers in Australia sought by boycotters and consumers, in general, and attributed its actions, at least in part, to the boycott campaigns.

1 The decision to not formulate specific hypotheses for moral disgust in the present study is mainly motivated by the absence, in the available research, of clear and strong evidence on important motivational and behavioral components for this specific form of disgust (i.e., social disgust). Most of the research available, in fact, focuses on nonsocial disgust such as reactions to disease, decaying bodies, or body sores (Nabi, 2002). The recent contribution by Hutcherson and Gross (2011) investigates specifically moral disgust showing that it is an adaptive general response to moral violations and not strongly associated with overt behavior, but largely with the attribution of immoral character to another person. Nevertheless, in the interest of strengthening results, empirical predictions with disgust are examined and compared with the main hypotheses.

2 It should be noted that this distinction roughly maps onto other taxonomies, including within-system and out-of-system consumer actions (Shaw \& Black, 2010), and reformism versus radicalism (Price \& Penaloza, 1993). This research approach is explicitly grounded in the psychology literature on moral emotions, whereas these other treatments are not. This permits one to more clearly provide a theory of motivation governing the distinct actions that consumers take in response to corporate wrongdoing.
By contrast, with destructive punitive actions, consumers want to harm the companies in response to being injured by those companies. To pursue this goal, consumers actively avoid companies' brands and spread messages that slander and discredit the firms. Both online and offline, consumers in fact try to actively voice their disapproval of company actions and to express their unhappiness so as to negatively affect the reputation of the company and encourage general brand disengagement in the market. Killercoke.org is an interesting example of an online space that focuses negative attention on a specific targeted brand and tries to create a negative online image for it (Krishnamurthy \& Kucuk, 2009). In this article, the goal is to expand understanding of the emotional processes motivating actions corresponding to these two different forms of consumers' reactions. ${ }^{3}$

It is proposed that anger leads to constructive punitive actions and contempt leads to destructive punitive actions. The rationales follow research on functional differences between anger and contempt in the psychology literature, maintaining that these emotions perform adaptive roles and reflect distinct appraisals and action tendencies. Although anger and contempt often correlate positively and both arise from negative appraisals of others' intentions (Frijda, Kuipers, \& ter Schure, 1989) and are hostile toward others in focus (Izard, 1971), there are important differences between these emotions in terms of their implications for social relationships.

Anger is a negatively valenced emotion initiated by events that people appraise in particular ways (e.g., Smith \& Lazarus, 1993) and that have social origins (Averill, 1982). So-called righteous anger or indignation emerges when a person is aware of or witnesses harm done to another person. The harm might be physical mistreatment or existential injury, such as occurs when the freedom or human dignity of another person

3 A pilot study was conducted to ensure that these different actions are perceived by consumers as being destructive or constructive against the company and, in addition, expression of a differential willingness to engage in future relationship with the company. A counterbalanced questionnaire describing eight specific behaviors was administered to 61 graduate and undergraduate students, asking them to indicate on 7-point strongly disagree to strongly agree scales, to what extent they believed that each behavior "aims to cut ties with the company," "tends to go away from the company," "was destructive to the company," and "was negative toward the company" (alpha $=0.88$ ). The ANOVA, conducted on the variable summarizing the four specific measures outlined above, highlighted in the post hoc test the existence of two categories of behaviors $(F=36.72, \mathrm{df}=7, p=0.00)$. All the behaviors related to participation in campaigns of public pressure via e-mail, picketing, participation in public events against the company, participation in organized pressure groups, and temporary boycott, formed the group of constructive punitive actions (the ANOVA on these five behaviors confirms that they belong to a single category: $F=0.73$, $\mathrm{df}=4, p=0.54)$. All the behaviors related to exercise negative word of mouth to generate negative public identity, discredit the company to harm its reputation, and recommend not to buy its products formed the group of destructive punitive actions (the ANOVA on these three behaviors confirms that they belong to a single category: $F=0.49, \mathrm{df}=2, p=0.62$ ). 
is violated. Righteous anger is to be contrasted to common anger which is a response of an individual when his/her own personal goal is blocked or threatened.

The experience of anger leads to a variety of responses or action-tendencies. Beyond such generalized inclinations as felt eagerness to act (e.g., HarmonJones, Singelman, Bohlig, \& Harmon-Jones, 2003) and indiscriminant urges to injure (e.g., Goldberg, Lerner, \& Tetlock, 1999; Kuppens, van Mechelen, Smits, \& de Boeck, 2003), anger provokes focused tendencies to punish specific perpetrators of misconduct, often with the hope of future reconciliation (Fischer \& Roseman, 2007). Thus, anger tends to be associated with attacking behavior but aims to improve the relationship that the attacker has with the target. In this way, anger is a constructive social emotion that functions to both correct wrongdoing and maintain or even strengthen the relationship one has with others. Therefore, it is hypothesized that

H1: Felt anger in response to corporate misconduct that mistreats other people will elicit constructive punitive actions toward the offender.

Contempt is a negatively valenced emotion characterized by disapproval of someone's actions and feeling morally superior to them. Contempt occurs in response to specific appraisals (Lazarus, 1991; Roseman, 1996). In particular, contempt shares with anger the criteria that a negative outcome is caused (1) by another agent (and not the self or circumstances beyond one's control), (2) with either certain or uncertain likelihood, and (3) under conditions where one feels that he/she has relatively high control to rectify the situation. Contempt differs from anger, in terms of certain antecedent appraisals, primarily in terms of evaluation of the target offender. For contempt, the offender is viewed as characterologically bad because of their character or status (e.g., being inferior, defective). For anger, the offender is simply seen as responsible for the bad outcome, without necessarily being construed as morally base.
The experience of contempt leads to various actiontendencies distinguished by urges to move away from or exclude the offender from one's relationship (e.g., Fischer \& Roseman, 2007). This is in contrast to the "move against" or "attack the offender urge," characteristic of anger action tendencies where one hopes to repair the relationship ultimately. In this sense, contempt is destructive of relationships rather than reparative as with anger and the goal is typically to break the relationship. Therefore, it is hypothesized that

H2: Felt contempt in response to corporate misconduct that mistreats other people will elicit destructive punitive actions toward the offender.

Figure 1 summarizes the hypotheses. The manipulation of corporate misconduct is expected to influence felt anger, contempt, and disgust, consistent with research in the CAD triad tradition (e.g., Rozin et al., 1999). By contrast, and in-line with the social-functionalist tradition (e.g., Hutcherson \& Gross, 2011), distinct consequences of anger and contempt are hypothesized. Anger is hypothesized to induce constructive punitive actions (H1) but not destructive punitive actions; contempt is hypothesized to elicit destructive punitive actions (H2) but not constructive punitive actions. Strong convergent and divergent hypotheses are thus made.

Measures of disgust are included in tests of hypotheses to establish stringent tests of the focal hypotheses concerning anger and contempt. Finally, Figure 1 also shows the role of altruistic values as control variables, that makes for a more rigorous test of hypotheses (see below) in that actions are expected to occur in response to emotional motivation, irrespective of whether consumers hold altruistic values or not.

\section{OVERVIEW OF STUDIES 1 AND 2}

Two studies were conducted to test the hypotheses, both of which examine the mediating role of anger and

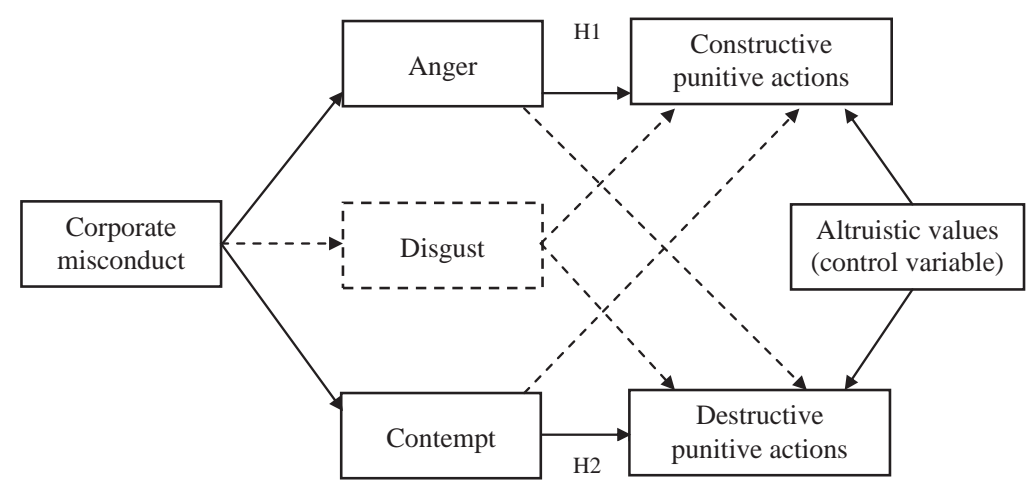

Figure 1. Conceptual framework of mediation processes.

Note: Dashed arrows are rival hypotheses tested in the analyses. 
Table 1. Confirmatory Factor Analysis: Construct Indicators, Factor Loadings, Means, and Reliability.

\begin{tabular}{|c|c|c|}
\hline & $\begin{array}{l}\text { Standardized } \\
\text { Factor } \\
\text { Loadings }\end{array}$ & $t$ \\
\hline \multicolumn{3}{|l|}{ Disgust } \\
\hline Disgusted & 0.75 & - \\
\hline Feeling distaste & 0.96 & $15.26^{* * *}$ \\
\hline Feeling revulsion & 0.93 & $15.10^{* * *}$ \\
\hline Means & 5.00 & \\
\hline Reliability & 0.90 & \\
\hline \multicolumn{3}{|l|}{ Anger } \\
\hline Mad & 0.90 & - \\
\hline Angry & 0.95 & $23.67^{* * *}$ \\
\hline Very annoyed & 0.97 & $19.40^{* * *}$ \\
\hline Means & 5.05 & \\
\hline Reliability & 0.93 & \\
\hline \multicolumn{3}{|l|}{ Contempt } \\
\hline Contemptuous & 0.86 & - \\
\hline Scornful & 0.89 & $17.07^{* * *}$ \\
\hline Disdainful & 0.79 & $14.32^{* * *}$ \\
\hline Means & 4.75 & \\
\hline Reliability & 0.88 & \\
\hline \multicolumn{3}{|l|}{ Destructive punitive actions } \\
\hline $\begin{array}{l}\text { Say to people negative things } \\
\text { about the company to } \\
\text { generate a negative public } \\
\text { identity }\end{array}$ & 0.89 & - \\
\hline $\begin{array}{l}\text { Discredit the company with } \\
\text { people to give it a bad } \\
\text { reputation }\end{array}$ & 0.83 & $16.50^{* * *}$ \\
\hline $\begin{array}{l}\text { Recommend people not to buy } \\
\text { products of this company }\end{array}$ & 0.88 & $17.83^{* * *}$ \\
\hline Means & 4.67 & \\
\hline Reliability & 0.90 & \\
\hline \multicolumn{3}{|l|}{ Constructive punitive actions } \\
\hline $\begin{array}{l}\text { Boycott the company in order to } \\
\text { have changes in its conducts }\end{array}$ & 0.77 & - \\
\hline $\begin{array}{l}\text { Participate in e-mail campaign } \\
\text { against the company in order } \\
\text { to have changes in its } \\
\text { conducts }\end{array}$ & 0.70 & $10.99^{* * *}$ \\
\hline $\begin{array}{l}\text { Participate in picketing against } \\
\text { the company in order to have } \\
\text { changes in its conducts }\end{array}$ & 0.78 & $12.49^{* * *}$ \\
\hline $\begin{array}{l}\text { Participate in collective } \\
\text { movements against the } \\
\text { company in order to have } \\
\text { changes in its conducts }\end{array}$ & 0.90 & $14.52^{* * *}$ \\
\hline $\begin{array}{l}\text { Participate in demonstration } \\
\text { against the company in order } \\
\text { to have changes in its } \\
\text { conducts }\end{array}$ & 0.67 & $10.41^{* * *}$ \\
\hline Means & 4.14 & \\
\hline Reliability & 0.87 & \\
\hline \multicolumn{3}{|l|}{ Altruistic values } \\
\hline Equality & 0.76 & - \\
\hline Social justice & 0.75 & $11.51^{* * *}$ \\
\hline Helping & 0.87 & $13.47^{* * *}$ \\
\hline Cooperation & 0.87 & $13.54^{* * *}$ \\
\hline Means & 5.76 & \\
\hline Reliability & 0.86 & \\
\hline
\end{tabular}

Table 1. Continued.

\begin{tabular}{lc}
\hline Fit indices & \\
$\chi^{2}(\mathrm{df})$ & $429.23(174)$ \\
CFI & 0.96 \\
NNFI & 0.95 \\
RMSEA & 0.07 \\
SRMR & 0.05 \\
\hline
\end{tabular}

${ }^{*} p<0.05 ;{ }^{* *} p<0.01 ;{ }^{* * *} p<0.001$.

contempt between perceived corporate wrongdoings and constructive and destructive punitive responses, respectively. The first study was a laboratory experiment. This study focuses on consumer's intentions as the dependent variables. To enhance external validity, a second study was done in the field based on an actual case of investigation of wrongdoing against the environment. The study was conducted in a context of consumer protests against corporate wrongdoings in Italy and examined violation appraisals, anger, and contempt as predictors of consumer intention to engage in constructive and destructive punitive actions against the real company.

\section{Measures}

The mediating variables were measured with three 7point items each, anchored with "very weak" and "very strong" and given in response to the query, "Based on the information you just read in the scenario, would you please express the degree to which you felt each of the following emotions?" These items (detailed in Table 1) were chosen based on basic research by Shaver, Schwartz, Kirson, and O'Connor (1987) showing the cognates of anger and contempt (see also Lazarus, 1991).

In addition, respondents were asked to indicate, on a 7-point scale, their intention to participate in eight different actions against the company in Study 1, and their actual behaviors in Study 2. Two different actions are analyzed: destructive punitive actions and constructive punitive actions (see Table 1).

Altruistic values were used as controls, based on Schwartz (1992). Responses were recorded on 7point scales with "not at all important" and "very much important" as end-points. Measures of altruistic values were included in tests of hypotheses to control for their possible effects as rival explanations of the role of the moral emotions of anger and contempt in inducing behavior against corporate wrongdoers.

\section{Measurement Assessment}

Structural equation modeling (LISREL 8.8) was used to assess convergent and discriminant validity of the measures. In a validation study of the instruments, 236 questionnaires were collected, and a CFA was 
Table 2. Likelihood Ratio Tests.

\begin{tabular}{|c|c|c|}
\hline & $\chi^{2}(\mathrm{df})$ & $\Delta \chi^{2}(\Delta \mathrm{df}) ; p$ \\
\hline $\begin{array}{l}\text { Model without } \\
\text { constrictions }\end{array}$ & $429.23(174)$ & - \\
\hline Disgust $=$ contempt & $437.08(175)$ & $7.85(1) ; p<0.01$ \\
\hline Disgust $=$ anger & $446.82(175)$ & $17.59(1) ; p<0.01$ \\
\hline Contempt $=$ anger & $434.83(175)$ & $5.60(1) ; p<0.01$ \\
\hline $\begin{array}{c}\text { Disgust }=\text { destructive } \\
\text { punitive actions }\end{array}$ & $436.54(175)$ & $7.31(1) ; p<0.01$ \\
\hline $\begin{array}{c}\text { Disgust }=\text { constructive } \\
\text { punitive actions }\end{array}$ & $456.86(175)$ & $27.63(1) ; p<0.01$ \\
\hline $\begin{array}{l}\text { Disgust }=\text { altruistic } \\
\text { values }\end{array}$ & $492.22(175)$ & $62.99(1) ; p<0.01$ \\
\hline $\begin{array}{l}\text { Contempt }=\text { destructive } \\
\text { punitive actions }\end{array}$ & $435.74(175)$ & $6.51(1) ; p<0.01$ \\
\hline $\begin{array}{l}\text { Contempt }=\text { construc- } \\
\text { tive punitive } \\
\text { actions }\end{array}$ & $432.18(175)$ & $2.95(1) ; p<0.01$ \\
\hline $\begin{array}{l}\text { Contempt }=\text { altruistic } \\
\text { values }\end{array}$ & $476.94(175)$ & $47.71(1) ; p<0.01$ \\
\hline Anger $=$ destructive & $472.02(175)$ & $42.79(1) ; p<0.01$ \\
\hline Anger $=$ constructive & $451.93(175)$ & $22.70(1) ; p<0.01$ \\
\hline $\begin{array}{l}\text { Anger }=\text { Altruistic } \\
\text { values }\end{array}$ & $442.31(175)$ & $13.08(1) ; p<0.01$ \\
\hline $\begin{array}{l}\text { Destructive punitive ac- } \\
\text { tions }=\text { constructive } \\
\text { punitive actions }\end{array}$ & $441.71(175)$ & $12.48(1) ; p<0.01$ \\
\hline $\begin{array}{l}\text { Destructive punitive } \\
\text { actions }=\text { altruistic } \\
\text { values }\end{array}$ & $473.23(175)$ & $44.00(1) ; p<0.01$ \\
\hline $\begin{array}{l}\text { Constructive punitive } \\
\text { actions = altruistic } \\
\text { values }\end{array}$ & $442.31(175)$ & $13.08(1) ; p<0.01$ \\
\hline
\end{tabular}

performed with mediators (contempt, anger, and disgust), dependent variables (destructive punitive actions and constructive punitive actions), and control variable (altruistic values; see Table 1 for factor loadings, means, and reliabilities). The fit of the model was $\operatorname{good}\left(\chi^{2}[\mathrm{df}]=429.23[174] ; \mathrm{CFI}=0.96 ; \mathrm{NNFI}=0.95\right.$; $\mathrm{SRMR}=0.05 ; \mathrm{RMSEA}=0.07)$, all factor loadings were high and significant, which, along with the good overall fit, suggests achievement of convergent validity. Likelihood ratio tests showed that the measures of all variables exhibited discriminant validity (see Table 2).

\section{STUDY 1}

By use of experimental and control conditions, corporate wrongdoings were manipulated. Narrative versions of the experimental and control conditions were developed, pretested, and then revised after pretesting. The negative stimulus narrative used a fictitious corporate name and began with a thorough description of the company and its irresponsible actions and their effects. Although the presented corporate name was fictitious, the narrative was based on actual corporate malfeasances perpetrated by companies over the years in the context in question. More specifically, a brief summary of the negative experimental narrative follows (the full versions of each narrative stimulus is available upon request from the authors):

"Dark Chocolate", a large manufacturer of confectioneries, farms and processes cocoa plants in Africa by use of child labor. Children are regularly conscripted, imprisoned, and physically abused to produce the chocolate.

The control narrative was a neutral description of the firm in question; it used the identical descriptive content of the firm as employed in the negative narrative. Only the corporate irresponsible actions were omitted.

\section{Method}

Respondents and Procedures. A total of 145 undergraduate and graduate students at an Italian university ( $52.4 \%$ female, $47.6 \%$ male; all between 19 and 28 years of age) were asked to participate in the study. The questionnaire took approximately 15 minutes to complete. After finishing the questionnaire, respondents were debriefed by explaining the purpose of the study, and thanked.

Measures. The factor analysis showed the following results: for contempt, factor loadings ranged from 0.96 to 0.97 , and Cronbach alpha was 0.97; for anger factor loadings ranged from 0.98 to 0.99 , and Cronbach alpha was 0.99 ; for disgust factor loadings ranged from 0.97 to 0.98, and Cronbach alpha was 0.97 . The factor analysis on outcome behaviors produced two factors corresponding to the two different types of action hypothesized: destructive punitive actions with factor loadings ranging from 0.86 to 0.95 , and Cronbach alpha of 0.94; and constructive punitive actions with factor loadings ranging from 0.84 to 0.92 , and Cronbach alpha of 0.94. The factor analysis on altruistic values demonstrated that the five altruistic items loaded on one factor with loadings ranging from 0.65 to 0.86 . Cronbach alpha was 0.78 .

\section{Results}

In the analysis, anger, contempt, and disgust were considered as possible mediators in order to show the significant differential role of the three moral emotions. Altruistic values were used as control variable in the analyses. ${ }^{4}$ To test the mediation hypotheses, the bootstrapping bias-corrected confidence interval procedure was used (Preacher, Rucker, \& Hayes, 2007; Zhao, Lynch, \& Chen, 2010). Also the Preacher and Hayes script (2008) was used to test for multiple mediation.

4 The control variable used had no effect. In constructive punitive actions analysis, the altruistic values effect was $-0.02(p=0.83)$, and in destructive punitive actions the effect was $-0.17(p=0.12)$. 
Constructive Punitive Actions. It was predicted that consumer feelings of anger mediate the relationship between corporate wrongdoings and constructive punitive actions. Specifically, a significant direct effect of corporate wrongdoings on anger was found $(-2.75$, $p<0.00$ ), and a significant direct effect of anger on constructive punitive actions $(1.00, p<0.01$; see Table 3). With respect to conditional indirect effects, a significant indirect effect of corporate wrongdoings on constructive punitive actions via anger was observed $(-2.75)$, with a $95 \%$ confidence interval excluding zero $(-3.85 ;-1.56)$. Therefore, the general hypothesis $\mathrm{H} 1$ is supported. The direct effect of corporate wrongdoings on constructive punitive actions (0.92) is not significant ( $p=0.11$ ), showing an indirect-only (i.e., full) mediation (Zhao, Lynch, \& Chen, 2010). No significant mediating effects of corporate wrongdoings on constructive punitive actions via contempt or via disgust were found, although the manipulation influenced both these negative emotions (see Table 3).

Destructive Punitive Actions. It was predicted that consumers' feelings of contempt mediate the relationship between corporate wrongdoings and consumers' destructive punitive actions. In particular, a significant direct effect of corporate wrongdoings on contempt was found $(-1.81, p<0.00)$, and a significant positive direct effect of contempt on destructive punitive actions $(0.79, p<0.01$; see Table 4$)$. With respect to conditional indirect effects, a significant indirect effect of corporate wrongdoings on destructive punitive actions via contempt was observed ( -1.42$)$, with a $95 \%$ confidence interval excluding zero $(-1.94 ;-0.97)$. Therefore, the general hypothesis $\mathrm{H} 2$ is supported. The direct effect of corporate wrongdoings on destructive punitive actions (1.19) was significant ( $p=0.04$ ), showing competitive mediation (Zhao, Lynch, \& Chen, 2010). No significant mediating effects of corporate wrongdoings on destructive punitive actions via anger or via disgust resulted (see Table 4).

\section{Discussion}

To summarize, these findings present evidence that different emotions underline different forms of consumer reactions to corporate wrongdoings. As expected, anger was related to the constructive punitive actions, but not to the destructive ones. Overall, these findings are in line with current basic research in psychology considering anger to be a constructive emotion that is likely to result in actions that allow for reconciliation (e.g., Fischer \& Roseman, 2007). Moreover, the study further provides evidences for the hypothesis that contempt predicts destructive punitive actions, confirming the nature of contempt as an excluding emotion proposed in the psychology literature for explaining general moral behavior (e.g., Fischer \& Roseman, 2007). Finally, findings show that disgust is not a significant predictor of these different types of consumer actions,
Table 3. Study 1-Constructive Punitive Actions: Results of Mediation Tests Using Bootstrapping Bias-Corrected Procedure.

\begin{tabular}{|c|c|c|c|c|}
\hline $\begin{array}{l}\text { Mediators: Anger, } \\
\text { Contempt, and } \\
\text { Disgust }\end{array}$ & $\begin{array}{l}\text { Unstand- } \\
\text { ardized } \\
\text { Estimates }\end{array}$ & SE & $t$ & $p$ \\
\hline \multicolumn{5}{|l|}{ Direct effects } \\
\hline $\begin{array}{l}\text { Manipulation on } \\
\text { constructive } \\
\text { punitive actions } \\
\text { (total) }\end{array}$ & -1.95 & 0.20 & 5.05 & 0.00 \\
\hline $\begin{array}{l}\text { Manipulation on } \\
\text { constructive } \\
\text { punitive actions } \\
\text { (direct) }\end{array}$ & 0.92 & 0.56 & -1.63 & 0.11 \\
\hline $\begin{array}{l}\text { Manipulation on } \\
\text { anger }\end{array}$ & -2.75 & 0.03 & -85.10 & 0.00 \\
\hline $\begin{array}{l}\text { Manipulation on } \\
\text { contempt }\end{array}$ & -1.81 & 0.06 & -30.69 & 0.00 \\
\hline $\begin{array}{l}\text { Manipulation on } \\
\text { disgust }\end{array}$ & -1.85 & 0.06 & -30.86 & 0.00 \\
\hline $\begin{array}{l}\text { Anger on constructive } \\
\text { punitive actions }\end{array}$ & 1.00 & 0.20 & 5.05 & 0.00 \\
\hline $\begin{array}{l}\text { Contempt on } \\
\text { constructive } \\
\text { punitive actions }\end{array}$ & -0.14 & 0.15 & -0.90 & 0.37 \\
\hline $\begin{array}{l}\text { Disgust on } \\
\text { constructive } \\
\text { punitive actions }\end{array}$ & 0.20 & 0.15 & 1.32 & 0.19 \\
\hline
\end{tabular}

Bootstrap 95\% confidence intervals for conditional indirect effect-bias-corrected and accelerated (BCa)

\begin{tabular}{lcccc}
\hline & \multicolumn{3}{c}{$\mathrm{SE}$} \\
& Effect & (boot) & Lower & Upper \\
\hline $\begin{array}{l}\text { Indirect effects } \\
\text { Manipulation on } \\
\quad \text { constructive }\end{array}$ & -2.87 & 0.63 & -4.06 & -1.66 \\
$\quad \begin{array}{l}\text { punitive actions via } \\
\text { anger, contempt, } \\
\text { and disgust (three }\end{array}$ & & & & \\
$\quad \begin{array}{l}\text { mediators) } \\
\text { Manipulation on } \\
\quad \text { constructive } \\
\text { punitive actions via } \\
\text { anger }\end{array}$ & -2.75 & 0.59 & -3.85 & -1.56 \\
$\begin{array}{l}\text { Manipulation on } \\
\text { constructive } \\
\text { punitive actions via } \\
\text { contempt }\end{array}$ & 0.24 & 0.31 & -0.41 & 0.83 \\
$\begin{array}{l}\text { Manipulation on } \\
\text { constructive } \\
\text { punitive actions via } \\
\text { disgust }\end{array}$ & -0.37 & 0.34 & -1.02 & 0.35 \\
\hline
\end{tabular}

Model summary for DV model.

$R^{2}=0.84 ; F(\mathrm{df})=145.16(5,139) ; p=0.00$.

confirming the weak relationship between this specific moral emotion and behaviors found recently in the basic psychology literature for general moral behavior (e.g., Hutcherson \& Gross, 2011). The next study further examines these hypotheses, but this time in a context of real corporate misconduct against the environment. 
Table 4. Study 1-Destructive Punitive Actions: Results of Mediation Tests Using Bootstrapping Bias-Corrected Procedure.

\begin{tabular}{|c|c|c|c|c|}
\hline $\begin{array}{l}\text { Mediators: Anger, } \\
\text { Contempt, and } \\
\text { Disgust }\end{array}$ & $\begin{array}{l}\text { Unstand- } \\
\text { ardized } \\
\text { Estimates }\end{array}$ & $\mathrm{SE}$ & $t$ & $p$ \\
\hline \multicolumn{5}{|l|}{ Direct effects } \\
\hline $\begin{array}{l}\text { Manipulation on } \\
\text { destructive punitive } \\
\text { actions (total) }\end{array}$ & -1.07 & 0.09 & -11.68 & 0.00 \\
\hline $\begin{array}{l}\text { Manipulation on } \\
\text { destructive punitive } \\
\text { actions (direct) }\end{array}$ & 1.19 & 0.58 & 2.05 & 0.04 \\
\hline $\begin{array}{l}\text { Manipulation on } \\
\text { anger }\end{array}$ & -2.75 & 0.03 & -85.10 & 0.00 \\
\hline $\begin{array}{l}\text { Manipulation on } \\
\text { contempt }\end{array}$ & -1.81 & 0.06 & -30.69 & 0.00 \\
\hline $\begin{array}{l}\text { Manipulation on } \\
\text { disgust }\end{array}$ & -1.85 & 0.06 & -30.86 & 0.00 \\
\hline $\begin{array}{l}\text { Anger on destructive } \\
\text { punitive actions }\end{array}$ & 0.28 & 0.20 & 1.36 & 0.18 \\
\hline $\begin{array}{l}\text { Contempt on } \\
\text { destructive punitive } \\
\text { actions }\end{array}$ & 0.79 & 0.16 & 4.50 & 0.00 \\
\hline $\begin{array}{l}\text { Disgust on destructive } \\
\text { punitive actions }\end{array}$ & 0.04 & 0.15 & 0.27 & 0.79 \\
\hline
\end{tabular}

Bootstrap 95\% confidence intervals for conditional indirect effect-bias-corrected and accelerated (BCa)

\begin{tabular}{|c|c|c|c|c|}
\hline & Effect & $\begin{array}{c}\mathrm{SE} \\
\text { (boot) }\end{array}$ & Lower & Upper \\
\hline \multicolumn{5}{|l|}{ Indirect Effects } \\
\hline $\begin{array}{l}\text { Manipulation on } \\
\text { destructive punitive } \\
\text { actions via anger, } \\
\text { contempt, and } \\
\text { disgust (three } \\
\text { mediators) }\end{array}$ & -2.26 & 0.57 & -3.55 & -1.23 \\
\hline $\begin{array}{l}\text { Manipulation on } \\
\text { destructive punitive } \\
\text { actions via anger }\end{array}$ & -0.76 & 0.53 & -1.99 & 0.20 \\
\hline $\begin{array}{l}\text { Manipulation on } \\
\text { destructive punitive } \\
\text { actions via contempt }\end{array}$ & -1.42 & 0.25 & -1.94 & -0.97 \\
\hline $\begin{array}{l}\text { Manipulation on } \\
\text { destructive punitive } \\
\text { actions via disgust }\end{array}$ & -0.08 & 0.24 & -.50 & 0.42 \\
\hline
\end{tabular}

\section{STUDY 2}

The purpose of Study 2 is to corroborate the results of Study 1 by using an actual case as the context of research. The study was conducted in Porto Torres, Sardinia, Italy, immediately after the corporate wrongdoing event. In January 2011, because of a breakdown of a company's tanker, more than 30,000 liters of oil spilled into the sea causing extensive damage to marine and wild life habitat and to local tourism and fishing industries. Over the years, this company had been involved in several environmental mishaps, and this oil spill was only the most recent one in a series of incidents. In this context, consumers' perceptions of the company violation and emotions were measured in relation to this violation, as predictors of consumer intentions to engage in constructive and destructive punitive actions.

\section{Method}

Respondents and Procedures. The survey was completed by 167 actual consumers living in Porto Torres during the week following the event: 71 men (42.5\%) and 96 women $(57.5 \%), 18 \%$ of participants are between 18 and 24 years old, $35.9 \%$ between 25 and 34 years old, $21.6 \%$ between 35 and 44 years old, $12 \%$ between 45 and 54 years old, and $12.6 \%$ over 55 years old. Undergraduate or higher educated respondents accounted for $15 \%$ of the sample, followed by respondents with a high school education (55.7\%) or less (29.3\%). The sample error, calculated on the entire Italian population, is $7.7 \%$, with a $95 \%$ confidence level.

The questionnaire took approximately 15 minutes to complete. After finishing the questionnaire, respondents were debriefed by explaining the purpose of the study, and thanked.

Measures. The appraisal of violation was measured by one 7-point item anchored with "very negative" and "very positive" and given in response to the query, "Based on the event described, how do you evaluate the company's behavior?" The factor analysis on moral emotions showed the following results: for contempt factor loadings ranged from 0.94 to 0.98 , and Cronbach alpha was 0.96; for anger loadings ranged from 0.84 to 0.91 , and Cronbach alpha was 0.86 ; for disgust loadings ranged from 0.87 to 0.96 , and Cronbach alpha was 0.91 . The factor analysis on behavioral intentions produced two factors corresponding to the two different types of action hypothesized: destructive punitive actions with factor loadings ranging from 0.80 to 0.92 , and Cronbach alpha of 0.89 ; and constructive punitive actions with factor loadings ranging from 0.72 to 0.90 , and Cronbach alpha of 0.91 . For altruistic values, the factor analysis demonstrated that the five altruistic items loaded on one factor with loadings ranging from 0.80 to 0.89 . Cronbach alpha was 0.91 .

\section{Results}

As in Study 1, to test the mediation hypotheses, the bootstrapping bias-corrected confidence interval procedure was used. Specifically, the Preacher-Hayes script (2008) for multiple mediations was employed. Also in these analyses, altruistic values were used as control variable. $^{5}$

5 The control variable used had no effect. In constructive punitive actions analysis, the altruistic values effect was $0.10(p=0.18)$ and in destructive punitive actions the effect was $0.08(p=0.34)$. 
Table 5. Study 2-Constructive Punitive Actions: Results of Mediation Tests Using Bootstrapping Bias-Corrected Procedure.

\begin{tabular}{|c|c|c|c|c|}
\hline $\begin{array}{l}\text { Mediators: Anger, } \\
\text { Contempt, and } \\
\text { Disgust }\end{array}$ & $\begin{array}{l}\text { Unstand- } \\
\text { ardized } \\
\text { Estimates }\end{array}$ & $\mathrm{SE}$ & $t$ & $p$ \\
\hline \multicolumn{5}{|l|}{ Direct effects } \\
\hline $\begin{array}{l}\text { Appraisal on } \\
\text { constructive } \\
\text { punitive actions } \\
\text { (total) }\end{array}$ & 0.74 & 0.14 & 5.49 & 0.00 \\
\hline $\begin{array}{l}\text { Appraisal on } \\
\text { constructive } \\
\text { punitive actions } \\
\text { (direct) }\end{array}$ & 0.49 & 0.13 & 3.67 & 0.00 \\
\hline Appraisal on anger & 0.39 & 0.13 & 3.08 & 0.00 \\
\hline Appraisal on contempt & 0.60 & 0.10 & 6.08 & 0.00 \\
\hline Appraisal on disgust & 0.47 & 0.12 & 3.91 & 0.00 \\
\hline $\begin{array}{l}\text { Anger on constructive } \\
\text { punitive actions }\end{array}$ & 0.52 & 0.09 & 5.67 & 0.00 \\
\hline $\begin{array}{l}\text { Contempt on } \\
\text { constructive } \\
\text { punitive actions }\end{array}$ & 0.18 & 0.10 & 1.79 & 0.07 \\
\hline $\begin{array}{l}\text { Disgust on } \\
\text { constructive } \\
\text { punitive actions }\end{array}$ & -0.13 & 0.10 & -1.30 & 0.19 \\
\hline
\end{tabular}

Bootstrap 95\% confidence intervals for conditional indirect effect-bias-corrected and accelerated (BCa)

\begin{tabular}{|c|c|c|c|c|}
\hline & Effect & $\begin{array}{c}\mathrm{SE} \\
\text { (boot) }\end{array}$ & Lower & Upper \\
\hline \multicolumn{5}{|l|}{ Indirect effects } \\
\hline $\begin{array}{l}\text { Appraisal on } \\
\text { constructive } \\
\text { punitive actions via } \\
\text { anger, contempt, } \\
\text { and disgust (three } \\
\text { mediators) }\end{array}$ & 0.25 & 0.10 & 0.09 & 0.46 \\
\hline $\begin{array}{l}\text { Appraisal on } \\
\text { constructive } \\
\text { punitive actions via } \\
\text { anger }\end{array}$ & 0.20 & 0.09 & 0.04 & 0.40 \\
\hline $\begin{array}{l}\text { Appraisal on } \\
\text { constructive } \\
\text { punitive actions via } \\
\text { contempt }\end{array}$ & 0.11 & 0.06 & -0.01 & 0.26 \\
\hline $\begin{array}{l}\text { Appraisal on } \\
\text { constructive } \\
\text { punitive actions via } \\
\text { disgust }\end{array}$ & -0.07 & 0.05 & -0.22 & 0.02 \\
\hline
\end{tabular}

Constructive Punitive Actions. Table 5 shows the findings for the influence of the appraisal of violation on constructive punitive actions as the outcome variable. It was predicted that consumers' feelings of anger mediate the relationship between appraisal of the violation and consumers' constructive punitive actions. Specifically, a significant direct effect of the appraisal of the violation on anger was found $(0.39, p<0.00)$, and a significant direct effect of anger on constructive punitive actions resulted $(0.52, p<0.01)$. With respect to conditional indirect effects, a significant indirect effect of appraisal of the violation on constructive punitive actions via consumers' anger was observed $(0.20)$, with a $95 \%$ confidence interval excluding zero $(0.04 ; 0.40)$. Therefore, the general hypothesis $\mathrm{H} 1$ is supported. The direct effect of the appraisal of violation on constructive punitive actions $(0.49)$ was significant $(p=0.00)$, showing complementary mediation (Zhao, Lynch, \& Chen, 2010). No significant mediating effects of appraisal of violation on constructive punitive actions via contempt and via disgust were found (see Table 5).

Destructive Punitive Actions. Table 6 shows the findings for the influence of the appraisal of violation on destructive punitive actions as the outcome variable.

Table 6. Study 2-Destructive Punitive Actions: Results of Mediation Tests Using Bootstrapping Bias-Corrected Procedure.

\begin{tabular}{|c|c|c|c|c|}
\hline $\begin{array}{l}\text { Mediators: Anger, } \\
\text { Contempt, and } \\
\text { Disgust }\end{array}$ & $\begin{array}{l}\text { Unstand- } \\
\text { ardized } \\
\text { Estimates }\end{array}$ & $\mathrm{SE}$ & $t$ & $p$ \\
\hline \multicolumn{5}{|l|}{ Direct effects } \\
\hline $\begin{array}{l}\text { Appraisal on } \\
\text { destructive punitive } \\
\text { actions (total) }\end{array}$ & 0.88 & 0.13 & 6.94 & 0.00 \\
\hline $\begin{array}{l}\text { Appraisal on } \\
\text { destructive punitive } \\
\text { actions (direct) }\end{array}$ & 0.50 & 0.12 & 6.94 & 0.00 \\
\hline Appraisal on anger & 0.39 & 0.13 & 3.08 & 0.00 \\
\hline Appraisal on contempt & 0.60 & 0.10 & 6.08 & 0.00 \\
\hline Appraisal on disgust & 0.47 & 0.12 & 3.91 & 0.00 \\
\hline $\begin{array}{l}\text { Anger on destructive } \\
\text { punitive actions }\end{array}$ & 0.05 & 0.08 & 0.58 & 0.57 \\
\hline $\begin{array}{l}\text { Contempt on } \\
\text { destructive punitive } \\
\text { actions }\end{array}$ & 0.69 & 0.09 & 7.63 & 0.00 \\
\hline $\begin{array}{l}\text { Disgust on destructive } \\
\text { punitive actions }\end{array}$ & -0.13 & 0.09 & -1.43 & 0.16 \\
\hline
\end{tabular}

Bootstrap 95\% confidence intervals for conditional indirect effect—bias-corrected and accelerated (BCa)

\begin{tabular}{|c|c|c|c|c|}
\hline & Effect & $\begin{array}{c}\mathrm{SE} \\
\text { (boot) }\end{array}$ & Lower & Upper \\
\hline \multicolumn{5}{|l|}{ Indirect effects } \\
\hline $\begin{array}{l}\text { Appraisal on } \\
\text { destructive punitive } \\
\text { actions via anger, } \\
\text { contempt, and } \\
\text { disgust (three } \\
\text { mediators) }\end{array}$ & 0.38 & 0.10 & 0.19 & 0.60 \\
\hline $\begin{array}{l}\text { Appraisal on } \\
\text { destructive punitive } \\
\text { actions via anger }\end{array}$ & 0.02 & 0.04 & -0.03 & 0.13 \\
\hline $\begin{array}{l}\text { Appraisal on } \\
\text { destructive punitive } \\
\text { actions via contempt }\end{array}$ & 0.42 & 0.11 & 0.22 & 0.64 \\
\hline $\begin{array}{l}\text { Appraisal on } \\
\text { destructive punitive } \\
\text { actions via disgust }\end{array}$ & -0.06 & 0.05 & -0.19 & 0.03 \\
\hline
\end{tabular}


It was predicted that consumers' feelings of contempt mediate the relationship between the appraisal of violation and consumers' destructive punitive actions. In particular, a significant direct effect of the appraisal of violation on contempt was found $(0.60, p<0.00)$, and a significant direct effect of contempt on destructive punitive actions $(0.69, p<0.01)$. With respect to conditional indirect effects, a significant indirect effect of the appraisal of violation on destructive punitive actions via consumers' contempt resulted (0.42), with a $95 \%$ confidence interval excluding zero $(0.22 ; 0.64)$. Therefore, the general hypothesis H2 is supported. The direct effect of the appraisal of violation on destructive punitive actions (0.50) was significant ( $p=0.00)$, showing complementary mediation (Zhao, Lynch, \& Chen, 2010). No significant mediating effects of appraisal of violation on destructive punitive actions were observed via anger and via disgust (see Table 6).

\section{Discussion}

The findings of this field study support hypotheses with respect to the roles of anger and contempt in mediating reactions to corporate wrongdoing on constructive and destructive punitive acts toward the wrongdoers. As hypothesized, anger mediated the effects of the corporate violation on constructive but not destructive actions; contempt mediated the effects of the corporate violation on destructive but not constructive actions; and disgust had no effects on either constructive or destructive actions.

\section{GENERAL DISCUSSION}

This study expanded on existing work on market activism, which has paid relatively little attention to the differentiation of consumer responses against corporate wrongdoings and to the emotional factors underlying such responses. To this end, work done on the functional differences among general moral emotions in the basic psychology literature was drawn upon (e.g., Fischer \& Roseman, 2007; Hutcherson \& Gross, 2011) and used to test several novel ideas regarding the relations between such emotions and consumers' constructive and destructive punitive actions, across two diverse contexts regarding corporate wrongdoings. The results are evaluated below in relation to the key predictions, and theoretical and managerial contributions are highlighted. Next, attention is directed to a number of limitations of the research, and suggested directions for further research in this area are detailed.

One contribution of the research is to show that consumers react behaviorally to corporate wrongdoing by committing two distinct forms of action: constructive punitive acts and destructive punitive acts. These diverging actions obviously have important ramifications for business. The marketing and business ethics literature have not systematically investigated and treated these actions as distinct behaviors. Rather the practice to date has been to study individual actions in depth with regard to either boycotts (e.g., Klein, Smith, \& John, 2004) or antibrand activism (e.g., Hollenbeck \& Zinkhan, 2010; Kozinets \& Handelman, 2004). Constructive punitive acts aim primarily to get wrongdoers to change their practices and make restitution, where appropriate, so as to create a sustaining relationship between firm and consumers, whereas destructive punitive acts strive to harm wrongdoers and to produce a break in the relationship and ultimately estrangement. Beyond finding evidence for the distinction between two kinds of actions directed at corporate wrongdoers, this research disclosed different etiologies governing their occurrence and developed and tested a theory to explain their functioning, which has been lacking in the literature to date.

A primary contribution of the findings is that qualitatively different emotions predict constructive and destructive punitive actions. Compelling evidence for hypotheses was found in that distinct consequences of relevance emanated from seemingly similar negative emotions_-anger and contempt_-according to wellformed theoretical mechanisms drawn from the basic psychological research literature. In addition, it was observed that disgust, while highly correlated with anger and contempt, and frequently confused with them in the literature and everyday speech, is not a significant predictor of these two types of actions, thereby ruling out rival hypotheses, and in general adding to the validity of the research findings.

Consistent with hypothesis, anger emerged as a significant predictor of willingness to engage in constructive punitive actions in the context of company wrongdoings against human rights (Study 1) and in a real context of corporate harm to the environment (Study 2 ). The hypothesis that anger should be less predictive of destructive punitive actions was also supported and in fact anger had no effect here. The finding that anger does not play a role in such forms of action might, at first sight, seem inconsistent with some previous work. Wetzer, Zeelenberg, and Pieters (2007), for example, have ascribed a central role to anger-related emotions in driving negative word of mouth. Furthermore, some empirical findings in the context of consumer dissatisfaction have shown a link between anger and both complaint intentions and intentions to engage in negative word of mouth (e.g., Diaz \& Ruíz, 2002; Folkes, Koletsky, \& Graham, 1987; Nyer, 1997). It should be noted, however, that this cited work did not control for contempt, and therefore the possibility cannot be excluded that the reported relation between anger and particular types of destructive punitive actions could have been due to shared variance between anger and contempt. In addition, the above-cited research focused more on negative arousal associated with anger and frustration and the impulsive behaviors that follow, rather than on the relation between the appraisal component of anger and instrumental forms of actions as examined in the current studies. 
These findings are, however, wholly in line with the view of anger as a constructive emotion that occurs in intimate relationships and functions to correct wrongdoing and uphold moral standards (see Averill, 1982; Fischer \& Roseman, 2007; Weber, 2004). This study has also shown that anger mostly results in actions that have beneficial consequences for social relations, which makes reconciliation possible (Averill, 1982; Fischer \& Roseman, 2007; Weber, 2004). In the context of market involvement against corporate wrongdoing, this means that consumers who feel angry about corporate wrongdoings may still feel connected to the firm in some way and, therefore, be more likely to engage with firms and work to sustain the relationship.

The findings regarding the hypothesis that contempt predicts destructive punitive actions were highly consistent across the two studies. In line with predictions, felt contempt predicted likelihood to engage in destructive punitive actions in the context of human rights violations (Study 1) and in a real context of company harm to the environment (Study 2). To the best of the authors' knowledge, this research is the first to provide evidence of this link. These findings are generally in line with the suggestion that contempt may be associated with particularly hostile reactions, because tendencies to harm others are not kept under control by the desire to preserve the relationship (Fischer \& Roseman, 2007). The results are also consistent with the idea that contempt, which implies a psychological distancing from its object, should play a key role in predicting actions that seek more radical changes and reorganizations of consumers who may come to support anticonsumption activities, not merely avoiding or shunning contact with offenders. Finally, disgust did not predict any of the punitive actions investigated in this research, confirming the inactive nature of this moral emotion as reported recently by Hutcherson and Gross (2011) in a basic psychology investigation.

Thus, by demonstrating that support for constructive punitive actions is associated with anger, that contempt rather than anger predicts destructive punitive actions, and that disgust has no causal effects, this study advances thinking and theory on the roles of emotions in predicting consumer responses to corporate wrongdoings. Further, the theoretical development and findings reveal subtle and sophisticated consumer behavior responses in that the same corporate infraction can lead to different emotional reactions and correspondingly unique effects on actions, depending on the nature of the emotion experienced.

The findings further underline the importance of testing theoretical models of market activism in relation to a variety of actions and contexts. The fact that different types of consumer reactions were taken into consideration and that predictions were generally confirmed across two very diverse contexts, and with different methods, speaks for the robustness of the theoretical ideas and affords confidence in the generalizability of the findings.
An investigation of the predictors of consumer actions against corporate wrongdoings is particularly timely, given the recent interest in issues related to understanding and addressing vigorous involvement by consumers in the marketplace by both academics (Lee, Fernandez, \& Hyman, 2009; Smith, Palazzo, \& Bhattacharya, 2010) and policy makers. This research answers recent calls to utilize insights from psychological and social science literatures (Bhattacharya, Korschun, \& Sen, 2009) to better understand consumers' reactions in the face of company misconduct. Counter to common beliefs that anger is an activating force for all forms of action from mild to drastic (Roseman, Wiest, \& Swartz, 1994), these findings suggest that the effects of anger are in fact more nuanced and strongly related to constructive actions and that it is contempt that is likely to drive destructive punitive actions. This underlines the importance of distinguishing among different types of consumer responses and of conducting theory-driven, empirical research to inform the discourse on consumer activism against corporations.

The findings also speak directly to current debates in marketing about the likely causes of, and effective responses to, extreme forms of consumer activism such as anticonsumption (Hollenbeck \& Zinkhan, 2010; Smith, Palazzo, \& Bhattacharya, 2010). These findings suggest that more extreme forms of actions are supported among consumers who feel contempt, an emotion that often develops when anger remains unaddressed (Fischer \& Roseman, 2007).

In terms of marketing practice, the crucial question is how to promote constructive forms of punitive actions and reduce the attractiveness of destructive forms of engagement in case of company misconduct. Thus, the challenge faced by companies lies in sponsoring the creation of inclusive spaces that provide consumers with the means to express their negative feelings and to participate in decision-making processes in order to redirect company activities. Such opportunities could prevent adverse levels of disaffection and contempt for the company. People engaging in or supporting constructive punitive actions feel in fact connected to the companies, and their activism should be viewed as expressions of the health of the relationship with the company rather than as threats to it. Unfortunately many companies often discourage consumer expressions of negative feedback. Nevertheless some independent organizations (e.g., planetfeedback.com) have assumed positive roles, helping customers to express their voice and priming positive responses by companies.

Furthermore, dangers for companies lie in not addressing the concerns of consumers expressed via constructive punitive actions. Such neglect is likely to breed contempt for the company and to reduce the perception that the relationship can be repaired and continued. This is surely what happened to such corporations as P\&G, after widespread collective actions against animal testing were ignored (www.uncaged. co.uk). 


\section{Limitations and Further Research}

It should be emphasized that this work does not represent a complete analysis of the factors underlying constructive and destructive punitive actions. It is therefore likely that other variables will further contribute to, mediate, or moderate, the relations tested in this work. For example, social identification, corporate reputation, perceived efficacy of the actions, and similar attachments to companies or perceptions of their responsiveness may insulate firms from negative actions and backlashes by consumers.

Likewise, other emotions might function in response to corporate misconduct. Some outcomes are so unusual and horrifying that the consumers might not know how to respond at first, beyond an initial reaction of shock and sorrow, such as recently happened in the Costa Concordia shipwreck off the coast of Italy, in January 2012. At the same time, assignment of responsibility frequently takes time to untangle, as "acts of God" need to be unsorted from wrong actions or failures to act by corporations. All this is to say that consumer responses often evolve through a process of emotional development along with interpretations of factual information that ebb and flow and that shift in degree of assigned responsibility as more is learned. As a consequence, some reactions to corporate irresponsibility start with self-focused, automatic emotional expressions of surprise, guilt, horror, and the like, but then later hone-in on other focused emotional reactions and action tendencies (acting against), such as anger, contempt, and gratitude, depending on the corporate response. Thus it is important in the study of some acts of corporate irresponsibility to take a processual point of view and follow the diverging paths of feeling and reasoning that evolve. Such possibilities remain to be explored.

Certain individual difference variables also may function to regulate consumer responses to corporate wrongdoing. For example, the strength of felt anger or contempt may depend on the degree of identification with a company and its brands. Consumer orientations to rewards and punishments, which have been found to differ in promotion versus prevention modes (e.g., Higgins, 1997), might direct actions in either constructive or destructive ways. Or the fit between promotions versus prevention orientations may interact with tendencies to make snap decisions versus wellplaned ones, to influence destructive versus constructive actions (Higgins, 2000). Other individual differences could be considered as well (e.g., empathy, shyness, individualism-collectivism, inner-other directedness, trust, or pridefulness).

Although basic psychological theory is clear in the implications of anger and contempt in moral contexts, and the findings herein support analogous outcomes for reactions to corporate irresponsibility, the possibility is left open that complex patterns of anger and contempt can occur, depending on the nature of wrongdoing and the conditions under which it occurs. For instance, as hinted above, anger can change in form (e.g., transform into rage) or evolve into contempt, if either the angry person fails to cope effectively with it or the firm responds inappropriately or does not respond at all. The conditions fostering or preventing such occurrences deserve scrutiny. At the same time, consumer responses may depend on social relationships, such as might happen when a group of consumers engages together in boycotting or protest. Here natural reactions of anger might morph into contempt, say, if a persuasive group member imposes his or her destructive tendencies on members of the group. More generally, social dynamics among group members should be studied to discover other contingencies shaping consumer responses to corporate irresponsibility. Consumers in brand communities may respond differently than individual consumers outside of these communities, for example.

Finally, although very little research has been done on the role of positive consumer emotional responses to CSR, it would be interesting to investigate whether consumers react with constructive and destructive actions toward corporations as a function of felt positive moral emotions. A recent study by Romani, Grappi, and Bagozzi (2013) represents a start in this direction and studies the role of gratitude.

\section{REFERENCES}

Averill, J. R. (1982). Anger and aggression: An essay on emotion. New York: Springer-Verlag.

Bhattacharya, C. B., Korschun, D., \& Sen, S. (2009). Strengthening stakeholder-company relationships through mutually beneficial corporate social responsibility initiatives. Journal of Business Ethics, 85, 257-272.

Diaz, A. B., \& Ruíz, F. J. (2002). The consumer's reaction to delays in service. International Journal of Service Industry Management, 13, 118-140.

Fischer, A. H., \& Roseman, I. J. (2007). Beat them or ban them: The characteristics and social functions of anger and contempt. Journal of Personality and Social Psychology, 93, 103-115.

Folkes, V. S., Koletsky, S., \& Graham, J. L. (1987). A field study of causal inferences and consumer reaction: The view from the airport. Journal of Consumer Research, 13, 534-539.

Friedman, M. (1996). Grassroots groups confront the corporation: Contemporary strategies in historical perspective. Journal of Social Issues, 52, 153-167.

Frijda, N. H., Kuipers, P., \& ter Schure, E. (1989). Relations among emotion, appraisal and emotional action readiness. Journal of Personality and Social Psychology, 57, 212-228.

Goldberg, J. H., Lerner, J. S., \& Tetlock, P. E. (1999). Rage and reason: The psychology of the intuitive prosecutor. European Journal of Social Psychology, 29, 781-795.

Haidt, J. (2001). The emotional dog and its rational tail: A social intuitionist approach to moral judgment. Psychological Review, 108, 814-834.

Haidt, J. (2003). Elevation and the positive psychology of morality. In C. L. M. Keyes \& J. Haidt (Eds.), Flourishing: Positive psychology and the life well-lived (pp. 275-289). Washington, D.C.: American Psychological Association.

Haidt, J. (2007). The new synthesis in moral psychology. Science, 316, 998-1002. 
Haidt, J., Koller, S. H., \& Dias, M. G. (1993). Affect, culture and morality, or is it wrong to eat your dog? Journal of Personality and Social Psychology, 65, 613-628.

Harmon-Jones, E., Singelman, J., Bohlig, A., \& Harmon-Jones C. (2003). Anger, coping, and frontal cortical activity: The effect of coping potential on anger-induced left frontal activity. Cognition \& Emotion, 17, 1-24.

Higgins, E. T. (1997). Beyond pleasure and pain. American Psychologist, 52, 1280-1300.

Higgins, E. T. (2000). Making a good decision: Value from fit. American Psychologist, 55, 1217-1230.

Hoffmann, S., \& Müller, S. (2009). Consumer boycotts due to factory relocation. Journal of Business Research, 62, 239247.

Hollenbeck, C. R., \& Zinkhan, G. M. (2006). Consumer activism on the internet: The role of anti-brand communities. In C. Pechmann \& L. Price (Eds.), Advances in Consumer Research, Vol. 33 (pp. 479-485). Duluth, MN: Association for Consumer Research.

Hollenbeck, C. R., \& Zinkhan, G. M. (2010). Anti-brand communities, negotiation of brand meaning, and the learning process: The case of Wal-Mart. Consumption Markets \& Culture, 13, 325-345.

Hutcherson, C. A., \& Gross, J. J. (2011). The moral emotions: A social-functionalist account of anger, disgust, and contempt. Journal of Personality and Social Psychology, 100, 719-737.

Izard, C. E. (1971). The face of emotion. New York: AppletonCentury-Crofts.

Izard, C. E. (1977). Human emotions. New York: Plenum Press.

Klein, J. G., Smith, N. C., \& John, A. (2004). Why we boycott: Consumer motivations for boycott participation. Journal of Marketing, 68, 92-109.

Kozinets, R. V., \& Handelman, J. M. (1998). Ensouling consumption: A netnographic exploration of boycotting behavior. In J. Alba \& W. Hutchinson (Eds.), Advances in Consumer Research, Vol. 25 (pp. 475-480). Provo, UT: Association for Cosumer Research.

Kozinets, R. V., \& Handelman, J. M. (2004). Adversaries of consumption: Consumer movements, activism, and ideology. Journal of Consumer Research, 31, 691-704.

Krishnamurthy, S, \& Kucuk, S. U. (2009). Anti-branding on the internet. Journal of Business Research, 62, 1119-1126.

Kuppens, P., van Mechelen, I., Smits, D. J. M., \& de Boeck, P. (2003). The appraisal basis of anger: Specificity, necessity and sufficiency of components. Emotion, 3, 254-269.

Laczniak, J. R., \& Murphy, P. E. (2012). Stakeholder theory and marketing: Moving from a firm-centric to a societal perspective. Journal of Public Policy and Marketing, 31, 284-292. doi: 10.1509/jppm.10.106

Lazarus, R. S. (1991). Emotion and adaptation. Oxford: Oxford University Press.

Lee, M. S. W., Fernandez, K. V., \& Hyman, M. R. (2009). Anticonsumption: An overview and research agenda. Journal of Business Research, 62, 145-147.

Micheletti, M. (2003). Political virtue and shopping: Individuals, consumerism, and collective action. New York: Palgrave.

Nabi, R. L. (2002). The theoretical versus the lay meaning of disgust: Implications for emotion research. Cognition \& Emotion, 16, 695-703.

Neilson, L. A. (2010). Boycott or buycott? Understanding political consumerism. Journal of Consumer Behaviour, 9, 214227.
Nyer, P. U. (1997). A study of the relationships between cognitive appraisals and consumption emotions. Journal of the Academy of Marketing Science, 25, 296-304.

Palazzo, G., \& Basu, K. (2007). The ethical backlash of corporate branding. Journal of Business Ethics, 73, 333346.

Preacher, K. J. \& Hayes, A. F. (2008). Asymptotic and resampling strategies for assessing and comparing indirect effects in multiple mediator models. Behavior Research Methods, 40, 879-891.

Preacher, K. J., Rucker, D. D., \& Hayes, A. F. (2007). Addressing moderated mediation hypotheses: Theory, methods, and prescriptions. Multivariate Behavioral Research, $42,185-227$.

Price, L. L., \& Penaloza, L. (1993). Consumer resistance: A conceptual overview. In L. McAlister \& M. L. Rothschild (Eds.), Advances in consumer research, Vol. 20 (pp. 123128). Provo, UT: Association for Consumer Research.

Romani, S., Grappi, S., \& Bagozzi, R. P. (2013). Explaining consumer reactions to corporate social responsibility: The role of gratitude and altruistic values. Journal of Business Ethics, 114, 193-206.

Roseman, I. J. (1996). Appraisal determinants of emotions: Constructing a more accurate and comprehensive theory. Cognition \& Emotion, 10, 241-278.

Roseman, I. J., Wiest, C., \& Swartz, T. S. (1994). Phenomenology, behaviors, and goals differentiate discrete emotions. Journal of Personality and Social Psychology, 67, 206-221.

Rozin, P., Lowery, L., Imada, S., \& Haidt, J. (1999). The CAD triad hypothesis: A mapping between three moral emotions (contempt, anger, disgust) and three moral codes (community, autonomy, divinity). Journal of Personality and Social Psychology, 76, 574-586.

Schwartz, S. H. (1992). Universals in the content and structure of values: Theoretical advances and empirical tests in 20 countries. In M. Zanna (Ed.), Advances in experimental social psychology (pp. 1-65). New York: Academic Press.

Sen, S., Gurhan-Canli, Z., \& Morwitz, V. (2001). Withholding consumption: A social dilemma perspective on consumer boycotts. Journal of Consumer Research, 28, 399417.

Shaver, P., Schwartz, J., Kirson, D., \& O'Connor, C. (1987). Emotion knowledge: Further explorations of a prototype approach. Journal of Personality and Social Psychology, $52,1061-1086$.

Shaw, D., \& Black, I. (2010). Market based political action: A path to sustainable development? Sustainable Development, 18, 385-397.

Shweder, R. A., Much, N. C., Mahapatra, M., \& Park, L. (1997). The "big three" of morality (autonomy, community, and divinity) and the "big three" explanations of suffering'. In A. Brandt \& P. Rozin (Eds.), Morality and health (pp. 119169). New York: Routledge.

Smith, C. A., \& Lazarus, R. S. (1993). Appraisal components, core relational themes, and the emotions. Cognition \& Emotion, 7, 233-269.

Smith, N. C., Palazzo, G., \& Bhattacharya, C. B. (2010). Marketing's consequences: Stakeholder marketing and supply chain corporate social responsibility issues. Business Ethics Quarterly, 20, 617-641.

Tangney, J. P., Stuewig, J., \& Mashek, D. J. (2007). Moral emotions and moral behavior. Annual Review of Psychology, 58, 345-372. 
Thompson, C. J., \& Arsel, Z. (2004). The Starbucks brandscape and consumers' (anticorporate) experiences of glocalization. Journal of Consumer Research, 31, 631642.

Turiel, E. (1983). The development of social knowledge: Morality and convention. Cambridge, England: Cambridge University Press.

Weber, H. (2004). Explorations in the social construction of anger. Motivation and Emotion, 28, 197-219.

Wetzer, I. M., Zeelenberg, M., \& Pieters, R. (2007). Never eat in that restaurant, I did!": Exploring why people engage in negative word-of-mouth communication. Psychology \& Marketing, 24, 661-680.

Zhao, X., Lynch, J. G., Jr., \& Chen, Q. (2010). Reconsidering Baron and Kenny: Myths and truths about mediation analysis. Journal of Consumer Research, 37, 197-206.

Correspondence regarding this article should be sent to: Richard P. Bagozzi, Stephen M. Ross School of Business, University of Michigan, 701 Tappan Street, Ann Arbor, Michigan 48109 (bagozzi@umich.edu). 